\title{
Morphological and cytological diversity of goldenrods (Solidago L. and Euthamia Nutt.) from south-western Poland
}

\author{
Magdalena Szymura $^{1 *}$, Tomasz H. Szymura ${ }^{2} \&$ Agnieszka Kreitschitz ${ }^{3}$
}

\author{
${ }^{1}$ Department of Agroecosystems and Green Areas Management, Wrocław University of Environmental and Life Sciences, pl. Grunwaldzki \\ 24A, 53-363 Wrocław, Poland \\ ${ }^{2}$ Mountain and Polar Ecosystems Laboratory Department of Ecology, Biogeochemistry and Environmental Protection, Wrocław University, \\ pl. Maksa Borna 9, 50-328 Wrocław, Poland \\ ${ }^{3}$ Department of Plant Morphology and Development, University of Wrocław, Kanonia 6/8, 50-328 Wrocław, Poland \\ * corresponding author (e-mail: magdalena.szymura@up.wroc.pl)
}

\begin{abstract}
Correlations between the morphology and cytology of invasive species and the effectiveness of invasion are among the most interesting questions in invasion ecology. Amongst exceptionally successful worldwide plant invaders, species of goldenrod (Solidago and Euthamia) are considered. The main aim of the study was to compare the morphology (concerning life traits) and cytology of the selected goldenrods occurring in south-western Poland with the effectiveness of their invasion. The results of the study, conducted in south-western Poland, showed that life traits of invasive Solidago and Euthamia taxa were clearly not connected with the effectiveness of invasion. The most widespread species, S. gigantea and S. altissima, had the highest ramets and uncommon species such as Euthamia graminifolia and S. virgaurea had short ramets. However, $S$. canadensis, which is tall, is also uncommon. The most frequent species (S. gigantea) produced smaller inflorescence than less frequent species (S. altissima, S. canadensis and Euthamia graminifolia). The spread of particular taxa was also not connected with the ploidy level and DNA content.
\end{abstract}

Key words: biological invasions, chromosome number, DNA content, invasive plant species, life traits

\section{Introduction}

Biological invasions are considered as a permanent component of environmental changes connected with human activities. The spread of alien plant species results in a loss of economic value, biological diversity and function of the invaded ecosystems (Richardson \& Pyšek 2006; Lambdon et al. 2008; Essl et al. 2011).

The effectiveness of invasion, characterised by the size of the occupied area and abundance of individuals, is determined by several factors connected with the environment in a new range of invasive species as well as plant biology (Essl et al. 2011; Pyšek \& Richardson 2008). An important factor is the residence time that passes during species introduction (Rejmánek 2000). Following the introduction into a new range and time, when aliens occur in a few isolated areas, there is a period of slow or lack of proliferation (lag phase). Subsequently, a phase of rapid range expansion and filling-in takes place. The period of lag phase usually ranges from 80 to 150 years (Lockwood et al. 2007).

Invasive plants are defined as widespread, non-native species that produce reproductive offspring - often in huge numbers - which have the potential to spread over a large area (Pyšek \& Richardson 2008). Several studies have focused on the reasons why plants, which are invasive, are more efficient in colonizing new areas than other plants (both native and alien species) which have no tendency to expand or invade. However, the biological mechanism of invasions still remains unclear (van Kleunen \& Richardson 2007; Schlaepfer et al. 2010a). The process of colonisation in new areas is generally 
controlled by two factors: competitiveness and dispersion ability (van Kleunen et al. 2010). Life traits such as plant height, inflorescence size and leaf number/size are frequently mentioned as factors ensuring effective invasion of alien species (Baker 1974; Szymura \& Szymura 2015). Bigger inflorescences produce more seeds and higher stems ensure better dispersion of seeds. However, some drawbacks connected with higher stems such as increased exposure of the apex to damages (e.g. caused by wind) can disturb this pattern (Wise \& Abrahamson 2010).

The spread of alien plants and their impact on the invaded vegetation is, in many cases, connected with the presence of polyploidy (Thompson 1991). Polyploidy allows plants to diversify their genome by its reorganization which increases adaptive plasticity (Mandák et al. 2003). Conversely, many naturalized alien plants have smaller genomes than their relatives which do not invade (Kubešova et al. 2010). Based on a variation in chromosome number, a variety in morphology is highly possible, including traits related to invasiveness such as stem height or inflorescence size (Stace 1989; Wise \& Abrahamson 2010).

Exceptionally successful worldwide plant invaders are goldenrods (Pyšek 1998; Weber 2003). It is one of the most complex genera of higher plants and variability within this genus is increased due to hybridization, introgression and ecological factors (Beaudry \& Chabot 1957; McNeil 1976; Semple et al. 1984).

In central Europe, five representatives of goldenrods (Solidago and Euthamia) were found. Only one taxon, $S$. virgaurea L. agg., is native. This taxon is considered as an aggregate species and divided into growing on lowlands Solidago virgaurea L. and growing in the mountains $S$. minuta L. (S. alpestris Waldst. et Kit.) (Kiełtyk \& Mirek 2014). The other four taxa are of American origin: S. gigantea Aiton, S. canadensis L., S. altissima L. (S. canadensis var. scabra (Muhl.) Torr. and Gray) and Euthamia graminifolia (L.) Nutt. The name commonly used for the last species in $\mathrm{Eu}-$ rope is Solidago graminifolia (L.) Elliot. However, on the basis of anatomical and DNA studies (Semple et al. 1981, 1984) conducted in America, the taxon should be classified to Euthamia Nutt. genus and its taxonomical correct name is Euthamia graminifolia (L.) Nutt.

Three of the introduced taxa ( $S$. gigantea, $S$. canadensis and S. altissima) are invasive and morphologically similar to each other. Up to now, the range of Euthamia graminifolia is limited to a few locations in Europe (Guzikowa \& Maycock 1986; Weber 1997). However, in recent years, a few new localities of this species were reported in Poland (Dajdok \& Nowak 2006; Kompała-Bąba \& Bąba 2006; Urbisz \& Urbisz
2006). Moreover, the pattern of biomass allocation in the case of $E$. graminifolia suggests its strong invasive potential (Szymura \& Szymura 2015).

In close proximity to the aforementioned Solidago, a hybrid species of alien Solidago canadensis s.l. with native $S$. virgaurea, called Solidago $\times$ niederederi was found in north-eastern Poland (Pliszko 2013; Migdałek et al. 2014). Moreover, numerous ornamental goldenrods e.g. Solidago hybrida, S. caesia, S. sphacelata and hybrid of Aster ptarmicoides $\times$ Solidago, called $\times$ Solidaster $\times$ luteus are cultivated in Europe.

Goldenrods are clonal perennial herbs with an extensive rhizome system. Stems of these species are single up to the inflorescence and non-flowering leaf rosettes are often present. In the stands of this modular organism, particular stems and/or rosettes are called ramets and considered as individual. The height of the ramets in the native range varies from 50 to 200 $\mathrm{cm}$ in the case of Solidago altissima and S. gigantea, and from 30 to $150 \mathrm{~cm}$ in S. candensis and Euthamia graminifolia (Semple \& Cook 2006). Inflorescences are fasciculate, thyrsoid (S. altissima, S. canadensis, S. gigantea, $S$. virgaurea) or form corymbose panicles (Euthamia graminifolia). Capitula are usually small and abundant and the florets are yellow. Seeds are multi-veined achenes with pappus-hair (McNeil 1976).

The taxonomical status of goldenrods which occur in Europe is still under discussion (Beaudry \& Chabot 1957; Guzikowa \& Maycock 1986; Weber 1997; Weber \& Schmid 1998). The taxonomical status of $S$. canadensis and S. altissima, in particular, is unclear. These species are difficult to differentiate (Rothmaler 2007; Rutkowski 2013) and in many papers are reported as two varieties of $S$. canadensis s.1.: var. canadensis and var. scabra (Guzikowa \& Maycock 1986; Weber 1997; Weber \& Schmid 1998). Semple (personal information), suggests that Solidago canadensis var. hargeri Fern., which occurs in Central Europe, has more hairy, lower stems than S. canadensis var. canadensis and, for this reason, is identified as $S$. altissima. However, the taxa differ in rhizome systems (Schmid et al. 1988) as well as in the morphological and micro-morphological features of the leaf epidermis (Szymura \& Wolski 2011). Unfortunately, these traits are difficult for instant application during field works. Other traits useful for distinguishing between the problematic taxa length and width of capitulum, as well as length of disc and ray florets, are suggested (Beaudry \& Chabot 1957; Weber 1997; Weber \& Schmid 1998; Rothmaler 2007; Rutkowski 2013). Previous studies revealed that particular Solidago species differ in morphological traits with the exception of S. altissima and $S$. canadensis. It was suggested that a morphological trait analysis which involves a higher number of indi- 
viduals and locations is needed (Szymura \& Szymura 2013).

The basic chromosome number in species of goldenrods is $\mathrm{x}=9$. Solidago virgaurea and Euthamia graminifolia are diploids $(2 \mathrm{n}=18)$. $S$. canadensis consists of diploid $(2 n=18)$ and tetraploid plants $(2 n=36)$, while $S$. altissima consists of hexaploid $(2 n=54)$, triploid $(2 n=27)$ and tetraploid $(2 n=36)$ cytotypes in the native range, whereas Solidago canadensis var. hargeri is diploid ( $2 \mathrm{n}=18$ ) (Semple et al. 1981, 1984, 2015). Solidago gigantea occurs in three different cytotypes: diploid $(2 \mathrm{n}=18)$, tetraploid $(2 \mathrm{n}=36)$ and hexaploid $(2 \mathrm{n}=54)$ (Weber \& Jabobs 2005; Schlaepfer et al. 2010b).

The main aim of this study was to compare the morphology (concerning life traits) and cytology of Solidago species which occur in Central Europe. We discuss the hypothesis that the effectiveness of invasion of particular Solidago species is correlated with life traits as well as ploidy level. That is to say, species with higher ramets, larger inflorescences and a higher ploidy level are more frequent. As a measure of the ef- fectiveness of invasion, the number of stands invaded by particular species is considered.

\section{Material and methods}

\subsection{Study site and studied taxa}

The study was conducted in Lower Silesia between 2010 and 2012. The distribution of Solidago taxa was surveyed on the basis of a sampling design arranged in $10 \times 10 \mathrm{~km}$ regular grid covering ca. $32,000 \mathrm{~km}^{2}$ (Fig. 1). The grid was established in accordance with the ATPOL grid and the sampled plots were placed in the centre of the ATPOL square (Zając 1978)

The individual sampling plot was a circle of 25 ha in size. All sampling plots were visited and species of goldenrods were searched for. If these species were present in this area, the stands of goldenrods located nearest to the center of the plot were analysed. If two or more species of goldenrods were found within an area of one plot, they were examined separately. In all, 309 plots were inspected.

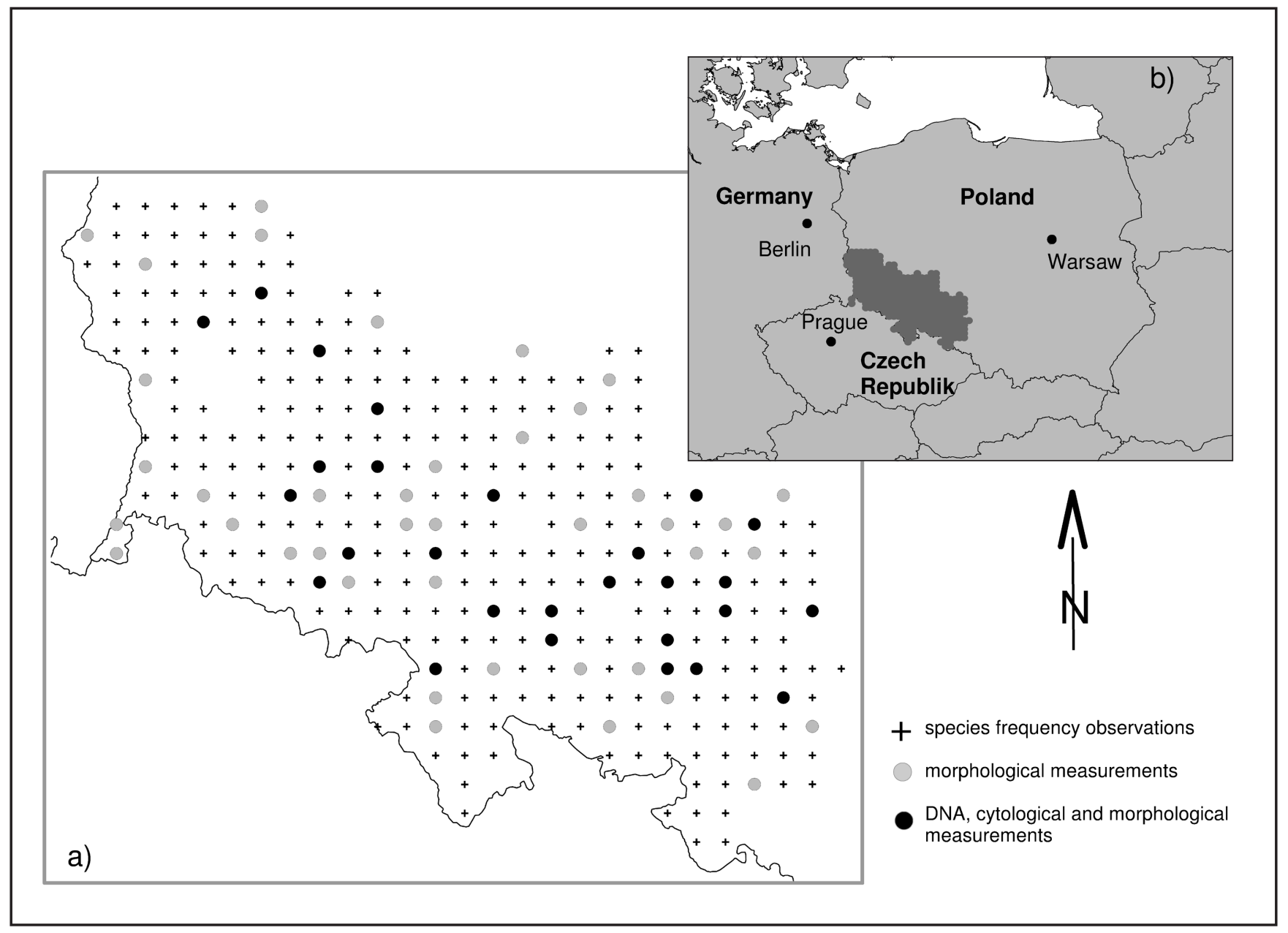

Fig. 1. Map of sampling plots arrangement (crosses, panel a) and location of the study area (panel b). The number of plots shown in the figure, selected to analyse, differs from the number of stands presented in the text ( 84 for morphological measurements, including 42 for DNA and cytological analysis) because, on some plots, stands of 2 or 3 taxa were presented 


\subsection{Morphological, cytological and molecular traits}

From 241 stands where goldenrods occurred, 84 stands were randomly selected for a detailed study (Fig. 1). The taxa were used as strata to provide a similar number of samples for each taxon. On the stands with 10 ramets per plot, the height of ramets, length and width of inflorescences and the number/size of leaves were measured. All morphological measurements were made in September 2011.

For 42 selected stands (Fig. 1), mature achenes were collected in September 2012 in order to study the chromosome numbers. The chromosome numbers were calculated in root tip meristems with 3 seedlings per plant. The achenes were left to germinate on wet filter paper in Petri dishes (in light conditions) and at room temperature. The seedlings were pre-treated with a $0,004 \mathrm{M}$ aqueous solution of 8-hydroxyquinoline for $4 \mathrm{~h}$ at $19-21^{\circ} \mathrm{C}$ in darkness. Afterwards, they were fixed in a 3:1 mixture of absolute ethanol:glacial acetic acid for at least $24 \mathrm{~h}$ at $4{ }^{\circ} \mathrm{C}$. Before staining, the root tips were hydrolysed with $5 \mathrm{M} \mathrm{HCl}$ for $1 \mathrm{~h}$ at room temperature (Kreitschitz \& Vallès 2003). The stained meristems were squashed in a drop of $45 \%$ acetic acid.

Young leaves, for the purpose of measuring DNA content, were collected from the same stands as seeds for the chromosome studies (Fig. 1). Five ramets per stand were studied, i.e. 200 samples in all. Measurements were made using flow cytometric analysis in the Laboratory of Molecular Biology and Cytometry of the University of Technology and Life Sciences in Bydgoszcz. For measurements, a Partec CCA (Münster, Germany) flow cytometer equipped with an argon laser was used. Leaves of particular Solidago taxa and of an internal standard (Zea mays $(2 \mathrm{C}=5.43 \mathrm{pg})$ ) were chopped simultaneously with a sharp razor blade in a plastic Petri dish with Galbraith buffer, supplemented with propidium iodide and ribonuclease A. After chopping, the suspension was passed through a $50 \mu \mathrm{m}$ mesh nylon filter. Analyses were replicated 10 times for each plant material.

\subsection{Statistical methods}

To check the significance of the differences between the studied groups, a Kruskal-Wallis nonparametric ANOVA rank was used. As a post-hoc test, a multiple comparison of median was conducted. All computations were made using Statistica 10 software.

\section{Results}

Species of goldenrods were present in 195 plots, i.e. in $63 \%$ of the inspected ones. Smooth goldenrod (Solidago gigantea) was the most numerous and was found in 125 stands. Late goldenrod (S. altissima) and
Canadian goldenrod (S. canadensis) were found in 116 and 21 stands, respectively. Grass-leaved goldenrod (Euthamia graminifolia) was found in only 8 stands. Common goldenrod ( $S$. virgaurea) was present in 11 stands, which were placed on lowlands or uplands, but not in the mountains, thus only $S$. virgaurea sensu stricto was analysed. The studied plants were found mostly on abandoned arable fields/meadows, road verges and habitat margins (e.g. forest margins, along fences, field margins).

\subsection{Morphological traits}

The studied species differed significantly in ramet height $(H=303.9, p=0.000)$. The post-hoc test revealed that they formed two groups. S. altissima, S. gigantea and $S$. canadensis belonged to the group of high plants, whereas Euthamia graminifolia and S. virgaurea belonged to the group of short plants (Fig. 2a). Generally, the two most frequent species ( $S$. altissima, $S$. gigantea) had tall ramets, whereas the uncommon species (Euthamia graminifolia and $S$. virgaurea) were short. However, the third tall species (S. canadensis) was also uncommon.

The species differed in leaf number $(\mathrm{H}=157.2$, $\mathrm{p}=0.000$ ). Post-hoc test revealed that the Euthamia graminifolia had the highest number of leaves and $S$. virgaurea - the lowest. The number of leaves of $S$. altissima and $S$. canadensis did not differ significantly (Fig. 2b).

S. gigantea and S. altissima had the longest leaves, whereby they did not differ to $S$. canadensis $(\mathrm{H}=6.253$, $\mathrm{p}=0.000$ ), (Fig. 2c). S. virgaurea and $S$. gigantea had the widest leaves. In the case of this trait, the differences between $S$. altissima and $S$. canadensis were also not significant ( $\mathrm{H}=131.3, \mathrm{p}=0.000)$, (Fig. 2d).

The size of inflorescences was the biggest in the case of S. altissima. This species had the longest (Fig. 2e) and widest (Fig. 2f) inflorescences. Smaller inflorescences were observed in $S$. gigantea, the most frequent species. The differences between $S$. altissima and $S$. canadensis in the case of inflorescence sizes were not significant.

\subsection{Chromosomes number and DNA content}

For most of the species (Solidago altissima, $S$. canadensis, S. virgaurea and Euthamia graminifolia), the diploid number $(2 \mathrm{n}=2 \mathrm{x}=18)$ was exclusively determined. All $S$. gigantea plants were tetraploid $(2 n=4 x=36)$.

The results of the DNA content analysis showed significant differences among species. The highest DNA content was observed in tetraploid S. gigantea and the lowest - in Euthamia graminifolia $(\mathrm{H}=169.3, \mathrm{p}=0.000)$, (Fig. 3, Table 1).

Intraspecies variability, which is variability among particular stands of a given taxa in DNA content, was 
a)

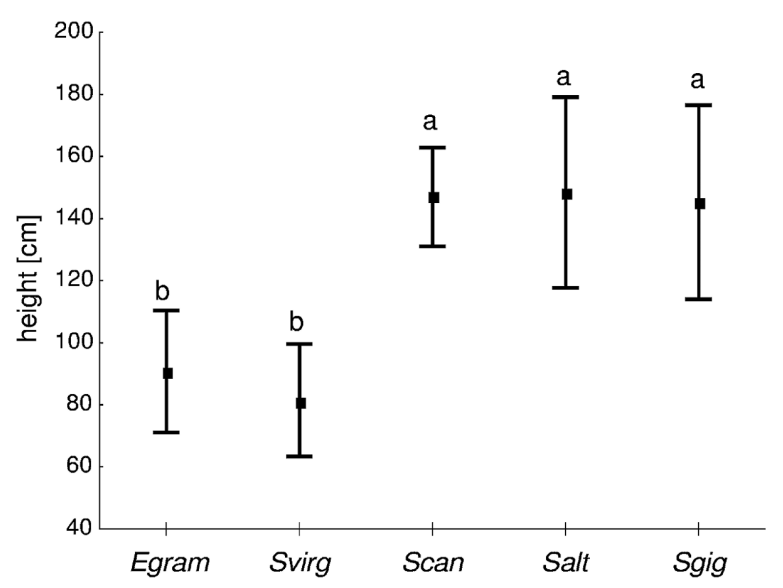

c)
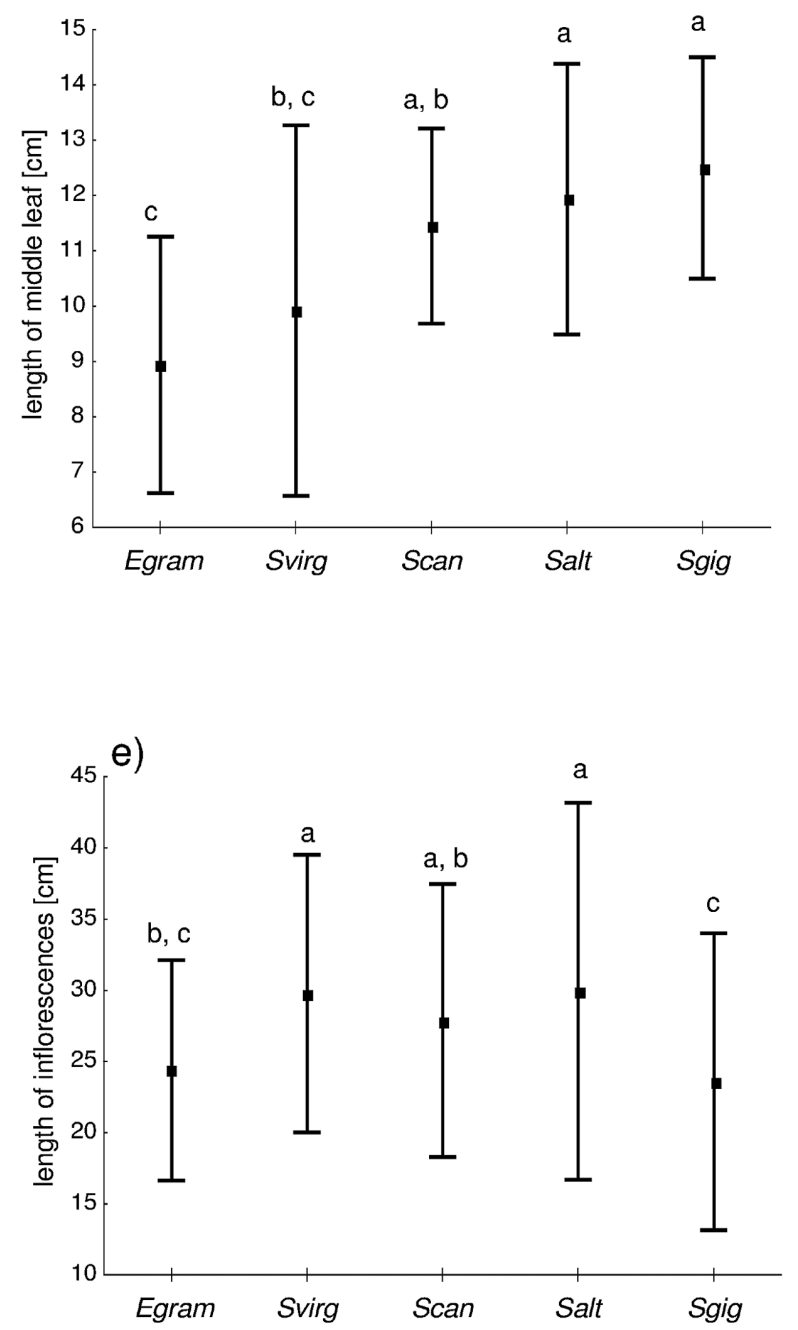

b)

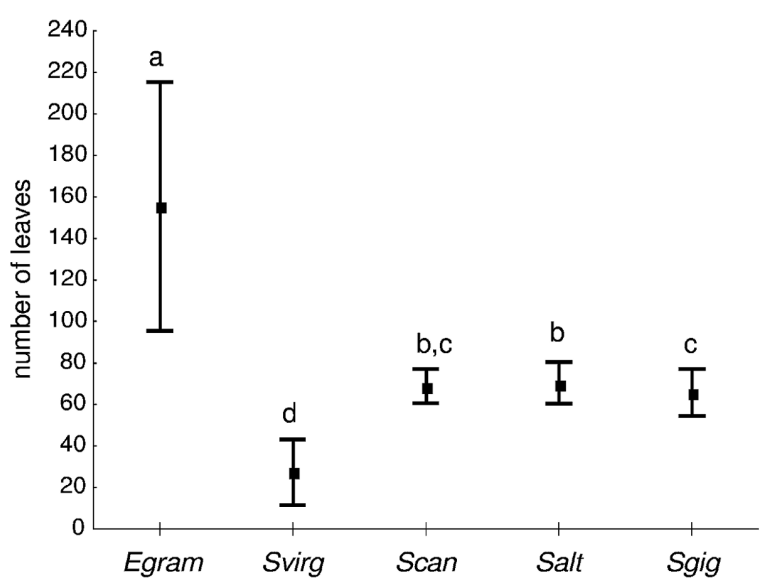

d)
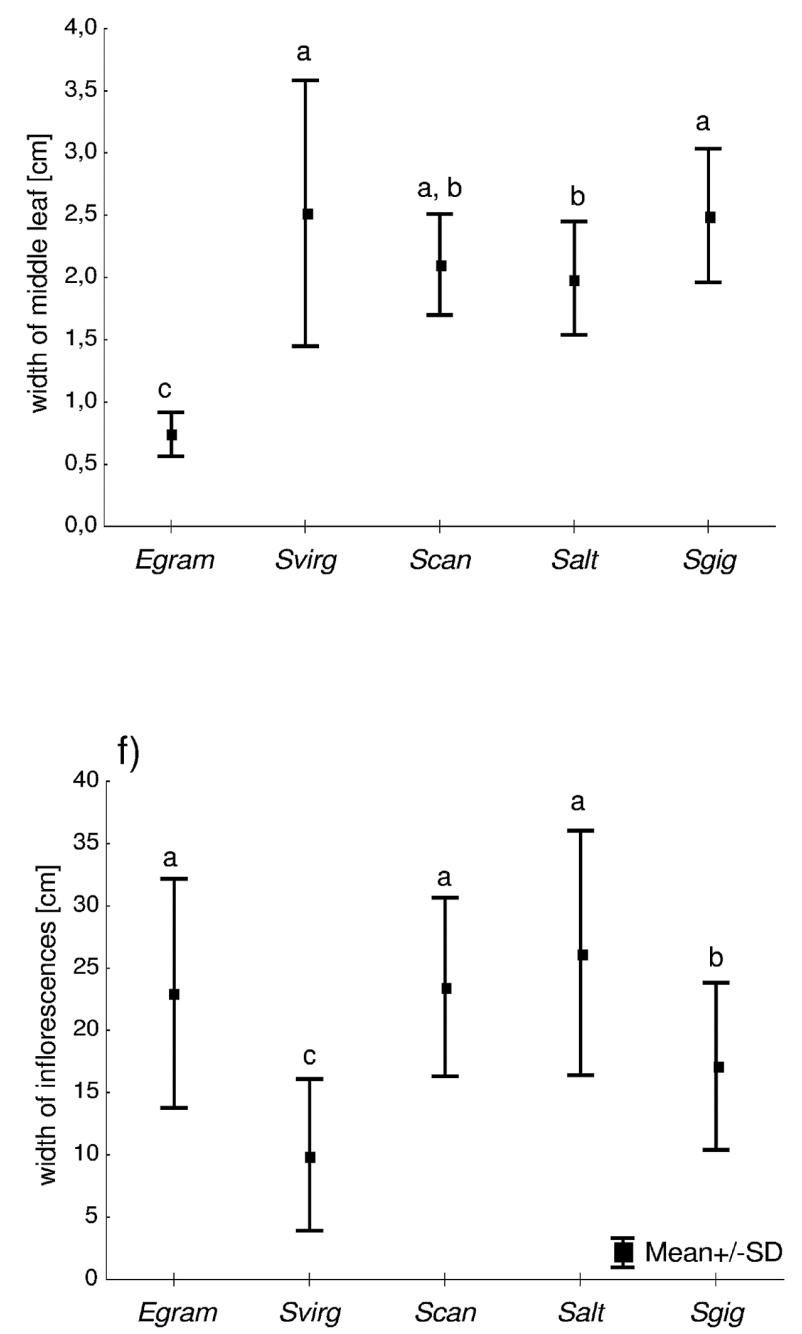

Fig. 2. Morphological traits of goldenrod taxa: a - height of ramets, $b$ - number of leaves, $c$ - length of leaves, $d$ - width of leaves, e-length of inflorescences, $\mathrm{f}$ - width of inflorescences

Explanations: significant differences were marked by different letters; mean value (points) and standard deviation (whiskers) are shown; Egram - Euthamia graminifolia, Svirg - Solidago virgaurea, Salt - S. altissima, Scan - S. canadensis, Sgig - S. gigantea 
Table 1. Chromosome number and DNA content in goldenrods taxa

\begin{tabular}{|c|c|c|c|c|}
\hline \multirow{2}{*}{ Sample } & \multirow{2}{*}{ Taxon } & \multicolumn{2}{|c|}{ DNA content [pg] } & \multirow{2}{*}{$\begin{array}{l}\text { Chromosome } \\
\text { number }(2 n)\end{array}$} \\
\hline & & mean & S.D. & \\
\hline 1 & Salt & 2.01 & 0.028 & 18 \\
\hline 2 & Salt & 2.05 & 0.022 & 18 \\
\hline 3 & Salt & 2.05 & 0.021 & 18 \\
\hline 4 & Salt & 2.04 & 0.021 & 18 \\
\hline 5 & Salt & 2.02 & 0.012 & 18 \\
\hline 6 & Salt & 2.05 & 0.007 & 18 \\
\hline 7 & Salt & 2.12 & 0.049 & 18 \\
\hline 8 & Salt & 2.07 & 0.017 & 18 \\
\hline 9 & Scan & 2.05 & 0.020 & 18 \\
\hline 10 & Scan & 2.03 & 0.033 & 18 \\
\hline 11 & Scan & 2.06 & 0.027 & 18 \\
\hline 12 & Scan & 2.03 & 0.035 & 18 \\
\hline 13 & Scan & 2.04 & 0.037 & 18 \\
\hline 14 & Scan & 2.21 & 0.097 & 18 \\
\hline 15 & Scan & 2.06 & 0.015 & 18 \\
\hline 16 & Scan & 2.04 & 0.017 & 18 \\
\hline 17 & Scan & 2.08 & 0.025 & 18 \\
\hline 18 & Sgig & 3.80 & 0.014 & 36 \\
\hline 19 & Sgig & 3.70 & 0.017 & 36 \\
\hline 20 & Sgig & 3.73 & 0.039 & 36 \\
\hline 21 & Sgig & 3.71 & 0.060 & 36 \\
\hline 22 & Sgig & 3.74 & 0.030 & 36 \\
\hline 23 & Sgig & 3.72 & 0.024 & 36 \\
\hline 24 & Sgig & 3.75 & 0.023 & 36 \\
\hline 25 & Sgig & 3.74 & 0.023 & 36 \\
\hline 26 & Sgig & 3.74 & 0.029 & 36 \\
\hline 27 & Sgig & 3.73 & 0.023 & 36 \\
\hline 28 & Sgig & 3.78 & 0.028 & 36 \\
\hline 29 & Sgig & 3.74 & 0.016 & 36 \\
\hline 30 & Sgig & 3.80 & 0.023 & 36 \\
\hline 31 & Sgig & 3.70 & 0.017 & 36 \\
\hline 32 & Egram & 1.92 & 0.031 & 18 \\
\hline 33 & Egram & 1.91 & 0.077 & 18 \\
\hline 34 & Egram & 1.92 & 0.033 & 18 \\
\hline 35 & Egram & 1.90 & 0.026 & 18 \\
\hline 36 & Egram & 1.95 & 0.027 & 18 \\
\hline 37 & Egram & 1.94 & 0.020 & 18 \\
\hline 38 & Egram & 1.95 & 0.017 & 18 \\
\hline 39 & Svirg & 2.36 & 0.036 & 18 \\
\hline 40 & Svirg & 2.34 & 0.015 & 18 \\
\hline 41 & Svirg & 2.36 & 0.018 & 18 \\
\hline 42 & Svirg & 2.34 & 0.023 & 18 \\
\hline
\end{tabular}

Explanations: Salt - Solidago altissima, Scan - S. canadensis, Scan/Salt - plants with intermediate traits between $S$. canadensis and $S$. altissima, Sgig - S. gigantea, Egram - Euthamia graminifolia, Svirg - S. virgaurea

also checked. There were significant differences among stands in S. altissima $(\mathrm{H}=15.089$, $\mathrm{p}=0.020)$, S. canadensis $(\mathrm{H}=17.093, \mathrm{p}=0.009)$. A significant difference was observed also in $S$. gigantea $(\mathrm{H}=38.63, \mathrm{p}=0.000)$. Stands of the remaining two species did not differ in DNA content (detailed results not shown).

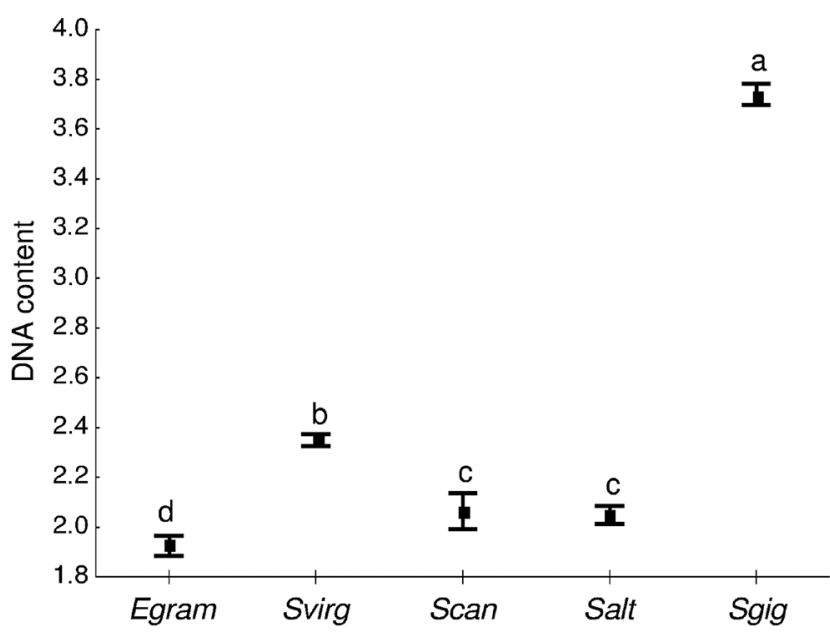

Fig. 3. DNA content of goldenrod taxa

Explanations: significant differences were marked by different letters; mean value (points) and standard deviation (whiskers) are shown; Egram - Euthamia graminifolia, Svirg - Solidago virgaurea, Salt - S. altissima, Scan - S. canadensis, Sgig - S. gigantea

\section{Discussion}

The studied taxa of goldenrods were introduced as ornamental plants from North America to London in the second part of the $17^{\text {th }}$ century. They were then distributed to gardens in different parts of Europe (Hitchmough et al. 2004). After a short time, the goldenrods "escaped" from cultivation and spread across Europe widely. The occurrence of Solidago gigantea in Poland was referred to earlier (in 1853) than S. canadensis s.1. (1872), and its spread had also been observed twenty years earlier - in 1940s (Tokarska-Guzik 2003). The results of this study suggest that $S$. gigantea is currently the most common species of goldenrods in south-western Poland. Euthamia graminifolia was introduced and naturalized at a similar time (1885); however, it only occurs in restricted areas with a low number of stands. It is considered as a species which is still in the lag phase of the invasion process (Weber 2001). However, recently a sudden spread of this species in different natural habitats has been observed (Dajdok \& Nowak 2006; Szymura \& Szymura 2011). It suggests that this species now reaches a phase of rapid range expansion during the invasion process. The native goldenrod, $S$. virgaurea, occurred sparsely in the studied area. This species exploits environmental resources less effectively and produces a few times less biomass than alien goldenrods (Szymura \& Szymura 2015).

Life traits of invasive goldenrods are not evident indicators of invasion effectiveness. The most widespread species, S. gigantea and S. altissima, have the highest ramets, while the uncommon species, Euthamia graminifolia and $S$. virgaurea, are short. However, $S$. 
canadensis, which belongs to the group of tall taxa, was also uncommon. With regards to inflorescence size, the most frequent species (S. gigantea) produced smaller inflorescences than the less frequent species (S. altissima, S. canadensis and Euthamia graminifolia). These results are in accordance with previous assessments but included a larger area (Szymura \& Szymura 2013). However, it should be mentioned that $S$. gigantea and Euthamia graminifolia invest more biomass in the below-ground parts (including rhizomes) than the remaining species (Schlaepfer et al. 2010a; Szymura \& Szymura 2015). Therefore, the observed above-ground traits indicating the invasiveness were not able to fully reflect the invasive potential of the species.

Despite the high diversity in chromosome number within the native range (Semple et al. 1981, 1984; Weber \& Jabobs 2005) in the studied area, only diploid plants of Solidago altissima, S. canadensis, Euthamia graminifolia were found and, in the case of S. gigantea, only tetraploid plants. This complies with data from Germany (Weber 1997, 2000) that in Europe only diploid plants of $S$. canadensis are noted. In $S$. altissima, the diploid chromosome level was also noted and the occurrence of additional B-chromosomes was observed (Małecka 1988; Musiał 1989). Only tetraploid populations of S. gigantea were found in Europe (Schlaepfer et al. 2008a, 2008b, 2010b). In the studied area, tetraploid taxon (Solidago gigantea) was the most numerous (present in 125 points) but, the second one (S. altissima) - which is a diploid - was present and plentiful (in 116 points). Tetraploid cytotypes of $S$. gigantea are more expansive than the diploid ones in the native range (Schlaepfer et al. 2008a), therefore, the polyploidy plays an important role in the invasion success of this taxon. S. altissima in its native range is most often hexaploid $(2 \mathrm{n}=54)$, but triploid $(2 \mathrm{n}=27)$ and tetraploid $(2 \mathrm{n}=36)$ cytotypes also occur (Semple et al. 1981, 1984; Weber 2000). It has been suggested that S. altissima developed as an allohexaploid by doubling the chromosomes of a hybrid between an 18-chromosome $S$. canadensis and 36-chromosome cytotype of S. gigantea (Beaudry \& Chabot 1957). In Europe, only diploid plants have been found (Weber 1997, 2000). It is likely that diploid races of $S$. altissima exist in North America. If such specimens are found, they may represent possible ancestors of the plants introduced in Europe (Weber 2000). The second explanation of the diploid status of $S$. altissima in Europe is that these plants belong actually to the taxon $S$. canadensis var. hargeri which is a diploid in America (Semple et al. 1981, 1984, 2015). Factors allowing the vast spread of this taxon in Europe are probably connected with its intensive reproduction system by generative and vegetative propagation, as well as wide tolerance for nutrient and soil moisture. S. altissima in Europe produces more than 10,000 seeds per shoot (Weber 2000). The small size of diaspores and the presence of pappus favours long-distance dispersal by wind. Established populations increase mainly by clonal growth. Individual clones have a long life span and can reach an age of 100 years (Weber 2000). However, a pattern could be found in the variation of DNA content and the frequency of occurrences of Solidago taxa. Significant differences in the DNA content of plants collected from different stands of S. gigantea, S. altissima, S. canadensis were observed in the studied area. Two of these taxa, namely $S$. altissima and S. gigantea are prevalent and common in the studied area. Numerous stands of these taxa in different environmental conditions occur which could both influence or be a result of variation in DNA content (Bennett et al. 2000; Śliwińska \& Thiem 2007; Kubešova et al. 2010). The other plants, whose stands differ according to DNA content, belong to Solidago canadensis. On the contrary, plants of Euthamia graminifolia from different stands did not differ with respect to their DNA content. Differences between the genome of this species should be expected on the basis of the 'genotypic' hypothesis of lag phase. It suggests that the lag phase is a time necessary for the development of different genotypes with increased dispersal ability (Pyšek \& Richardson 2008). However, in a recently observed situation of rapid spread of this taxon, differentiation in DNA content was not found. The lack of significant differences was also observed in native taxon ( $S$. virgaurea). However, in the studied area, only plants which grew on lowland localities were observed. The results could change if stands of $S$. minuta were included in the analysis (Kiełtyk \& Mirek 2014).

\section{Conclusions}

- Life traits of invasive goldenrods did not precisely indicate their effectiveness of invasion. The most widespread species, S. gigantea and S. altissima, had the highest ramets and the uncommon species, S. virgaurea and Euthamia graminifolia, were short. However, $S$. canadensis, which was tall, was also uncommon. Furthermore, the most frequent species, $S$. gigantea, produced smaller inflorescences than less frequent species such as S. altissima, S. canadensis and Euthamia graminifolia.

- Tetraploid taxon (Solidago gigantea) was the most numerous in the studied area (present in 125 stands), but the second one (S. altissima), which was a diploid, was present in 116 stands. The other taxa occurred in a much smaller number of stands. As a result, the spread of particular taxa was most likely connected not only to ploidy level. 
- The pattern in variation of DNA content and frequency of occurrences of taxa of goldenrods could be defined. Stands of less frequent species (Euthamia graminifolia and Solidago virgaurea) did not differ with respect to DNA content.

Acknowledgements. We would like to thank Professor E. Śliwińska and the team from Laboratory of Molecular Biol- ogy and Cytometry of University of Technology and Life Sciences in Bydgoszcz for the measurements of DNA content. The study was supported by grants: NCN (N N305 401438), the Wrocław University of Environmental and Life Sciences, and the University of Wrocław.

\section{References}

BAKer H. G. 1974. The evolution of weeds. Annual Review of Ecology and Systematics 5: 1-24.

Beaudry J. R. \& Снавот D. L. 1957. Studies on Solidago L. I. S. altissima L. and S. canadensis L. Contr. Institute of Botany University of Montreal, Quebec 70: $65-72$.

Bennett M. D., Bhandol P., \& Leitch I. J. 2000. Nuclear DNA amounts in angiosperms and their modern uses-807 new estimates. Annals of Botany 86(4): 859-909.

DAJDok Z. \& NowaK A. 2006. Solidago graminifolia (L.) Elliott in Poland - spreading and habitat preferences. In: B. ToKARSKA-GuziK \& K. Edwards (eds.). Plant Invasions, p. 20. Backhuys Publishers, Leiden, The Netherlands.

Essl F., Dullinger S., Rabitsch W., Hulme P. E., Hülber K., Jarošík V., Kleinbauer I., Krausmann F., Kühn I., Nentwi W., Vilà M., Genovesi P., Gherardi F., Desprez-Loustau M.L., Roques A. \& Pyšek P. 2011. Socioeconomic legacy yields an invasion debt. Proceedings of the National Academy of Sciences, 108(1): 203-207.

GuZIKowa M. \& MAYCock P.F. 1986. The invasion and expansion of three North American species of goldenrod (Solidago canadensis L. sensu lato, S. gigantea Ait. and S. graminifolia (L.) Salisb. in Poland. Acta Soc. Bot. Pol. 55: 367-384.

Hitchmough J., De La Fleur M. \& Findlay C. 2004. Establishing North American prairie vegetation in urban parks in northern England. Part 1. Effect of sowing season, sowing rate and soil type. Landscape Urban. Plann. 66: 75.90.

Kiętyk P. \& Mirek Z. 2014. Taxonomy of Solidago virgaurea group (Asteraceae) in Poland, with special reference to variability along the altitudinal gradient. Folia Geobotanica 49: 259-282.

van Kleunen M. \& Richardson D. M. 2007. Invasion biology and conservation biology: time to join forces to explore the links between species traits and extinction risk and invasiveness. Progress in Physical Geography 31: 447-603.

van Kleunen M., Dawson W., Schlaepfer D., Jeschke J. M. \& FISCHER M. 2010. Are invaders different? A conceptual framework of comparative approaches for assessing determinants of invasiveness. Ecology Letters 13: 947-958.
Kompala-BąBA, A. \& W. BąBA. 2006. Solidago graminifolia (L.) Elliott on anthropogenic sites of the Silesian Upland Poland. Biodiv. Res. Conserv. 3-4: 329-332.

Kreitschitz A. \& Vallès J. 2003. New or rare data on chromosome numbers in several taxa of the genus Artemisia (Asteraceae) in Poland. Folia Geobotanica 38(3): 333-343.

Kubešova M., Moravcová L., Suda J., JarošiK V. \& PYšEK P. 2010. Naturalized plants have smaller genomes than their non-invading relatives: a flow cytometric analysis of the Czech alien flora. Preslia 82: 81-96.

Lambdon P. W., Pyšek P., Basnou C., Hejda M., Arianoutsou M., Essl F., Jarošík V., Pergl J., Winter M. Anastasiu P., Andriopoulos P., Bazos I., Brundu G., Celesti-Grapow L., Chassot P. \& Vilà M. 2008. Alien flora of Europe: species diversity, temporal trends, geographical patterns and research needs. Preslia. 80: 101-149.

Lockwood J.L., Hoopes M. F. \& MARChETTI P. 2007. Invasion ecology. 303 pp. Blackwell Publishing, USA.

McNeil J. 1976. Solidago L., In: T. G. Tutin, V. H. Heywood, N. A. Burges, D. H. Valentine, S. M. Walters \& D. A. Webв (eds.). Flora Europaea, 4, pp. 110-111. Cambridge University Press, Cambridge.

MalecKa J. 1988. Studies on the genus Solidago L. I. Karyotype analysis of Solidago canadensis L. s.l. Acta Biol. Crac. ser. Botanica 30: 137-145.

Mandák B., Pyšek P., Lysák M., Suda J., Krahulcova A. \& Bímova K. 2003. Variation in DNA-ploidy levels of Reynoutria taxa in the Czech Republic. Annals of Botany 92: 265-272.

Migdałek G., Kolczyk J., Pliszko A., Kościńska-Pająk M. \& SŁOмKA A. 2014. Reduced pollen viability and achene development in Solidago $\times$ niederederi Khek from Poland. Acta Soc. Bot. Pol. 83(3): 251-255.

Musiat K. 1989. Studies on the genus Solidago L. III Embriology of Solidago canadensis var. canadensis. Acta Biol. Crac. ser. Botanica 31: 73-84.

Pliszko A. 2013. A new locality of Solidago $\times$ niederederi Khek (Asteraceae) in Poland. Biodiv. Res. Conserv. 29: 57-62.

PYŠEK P. 1998. Alien and native species in Central European urban floras: a quantitative comparison. Journal of Biogeography 25: 155-163. 
PYŠEK P. \& RichaRdSON D. M. 2008. Invasive plants. In: S. E. Jørgensen \& B. D. Fath (eds.). Ecological Engineering, vol. 3 of Encyclopedia of Ecology, pp. 2011-2020. Elsevier, Oxford.

REJMÁNEK M. 2000. Invasive plants: approaches and predictions. Austral ecology 25(5): 497-506.

RichARDSOn D. M. \& PYŠEK P. 2006. Plant invasions: merging the concepts of species invasiveness and community invasibility. Progr. Phys. Geogr. 30: 409-431.

Rothmaler W. 2007. Exkursionsflora von Deutschland. Band 3, 753 pp. Elsevier, Spektrum Akademischer Verlag, München.

RutKowski L. 2013. Klucz do oznaczania roślin naczyniowych Polski niżowej. 814 pp. PWN, Warszawa.

Schlaepfer D. R., Edwards P. J., Semple C. J. \& Billeter R. 2008a. Cytogeography of Solidago gigantea (Asteraceae) and its invasive ploidy level. J. Biogeogr. 35: 2119-2127.

Schlaepfer D. R., Edwards P. J., Widmer A. \& Billeter R. 2008b. Phylogeography of native ploidy levels and invasive tetraploids of Solidago gigantea. Mol Ecol. 17: 5245-5256.

Schlaepfer D. R., Glättli M., Fischer M. \& van Kleunen M. 2010a. A multi-species experiment in their native range indicates pre-adaptation of invasive alien plant species. New Phytologist 185: 1087-1099.

Schlaepfer D. R., Edwards P. J. \& Billeter R. $2010 \mathrm{~b}$. Why only tetraploid Solidago gigantea (Asteraceae) became invasive: a common garden comparison of ploidy levels. Oecologia 163: 661-673.

Schmid B., Puttick G. M., Burgess K. H. \& Bazzaz F. A. 1988. Correlations between genet architecture and some life history features in three species of Solidago. Oecologia 75: 459-464.

Semple J. C., Brammall R. A. \& Chmielewski J. 1981. Chromosome numbers of goldenrods, Euthamia and Solidago (Compositae-Asteraceae). Can. J. Bot. 59: 1167-1173.

Semple J. C \& Cook R. E. 2006. Solidago. In: North America Editorial Committee (eds.). Flora of North America, pp. 107-166. Oxford University Press, Oxford.

Semple J. C., Ringius G. S., Leeder C. \& Morton G. 1984. Chromosome numbers of Goldenrods, Euthamia and Solidago (Compositae-Asteraceae). II Additional counts with comments on cytogeography. Brittonia 36(3): 280-292.

Semple J. C., H. Rahman H., Bzovsky S., Sorour M. K., Kornobis K., Laphitz R. L. \& Tong L. 2015. A multivariate morphometric study of the Solidago altissima complex and S. canadensis (Asteraceae: Astereae). Phytoneuron 2014-10: 1-31.

Stace C. A. 1989. Plant taxonomy and biosystematics. 272 pp. Edward Arnold, London.
Szymura M. \& Szymura T. H. 2011. Rozmieszczenie nawłoci (Solidago spp.) na obszarze Dolnego Śląska oraz ich wpływ na różnorodność biologiczną zasiedlanych fitocenoz. Acta Bot. Siles. 6: 195-212.

Szymura M. \& Szymura T. H. 2013. Soil preferences and morphological diversity of goldenrods (Solidago L.) from south-western Poland. Acta Soc. Bot. Pol. 82(2): 107-115.

Szymura M. \& Szymura T. H. 2015. Growth, phenology, and biomass allocation of alien Solidago species in Central Europe. Plant Species Biology. Doi: 10.1111/14421984.12059.

SZYMURA M. \& WolsKi K. 2011. Leaf epidermis traits as tools to identify Solidago L. taxa in Poland. Acta Biol. Crac. ser. Botanica 53(1): 38-46.

ŚLIwiŃska E. \& Thiem B. 2007. Genome size stability in six medicinal plant species propagated in vitro. Biologia Plantarum 51(3): 556-558.

Thompson J. D. 1991. The biology of an invasive plant. What makes Spartina anglica so successful? BioScience 41: 393-401.

ToKARSKA-GuZIK B. 2003. The expansion of some alien plant species (neophytes) in Poland. In: L. E. Child, J. H. Brock, G. Brundu, K. Prach, P. Pyšek, P. M. Wade \& M. Wiliamson (eds.), Plant Invasions: Ecological Treats and Management Solutions, pp. 147-167. Backhuys Publishers, Leiden, The Netherlands.

URBISZ A. \& URBISZ A. 2006. Invasive vascular plant species in the south-western part of the Silesian Upland (south Poland). Biodiv. Res. Conserv. 1-2:143-146.

Weber E. 1997. Morphological variation of the introduced perennial Solidago canadensis L. sensu lato (Asteraceae) in Europe. Bot J Linn Soc 123: 197-210.

Weber E. 2000. Biological flora of Central Europe: Solidago altissima L. Flora 195: 123-134.

Weber E. 2001. Current and potential ranges of three exotic goldenrods (Solidago) in Europe. Conservation Biology 15(1): 122-128.

Weber E. 2003. Invasive Plant Species of the World. A reference Guide to Environmental Weeds. CABI Publishing, Oxon, UK.

WeBer E. \& JACOBS G. 2005. Biological flora of central Europe: Solidago gigantea Aiton. Flora 200: 109-118.

Weber E. \& Schmid B. 1998. Latitudinal population differentiation in two species of Solidago (Asteraceae) introduced into Europe. Am. J. Bot. 85: 1110-1121.

Wise M. J. \& Abrahamson W. G. 2010. Genetic variation for susceptibility to storm-inducted stem breakage in Solidago altissima: The role of stem height and morphology. Acta Oecol. 36: 372-376.

ZAJAC A. 1978. Atlas of distribution of vascular plants in Poland (ATPOL). Taxon 27(5-6): 481-484. 